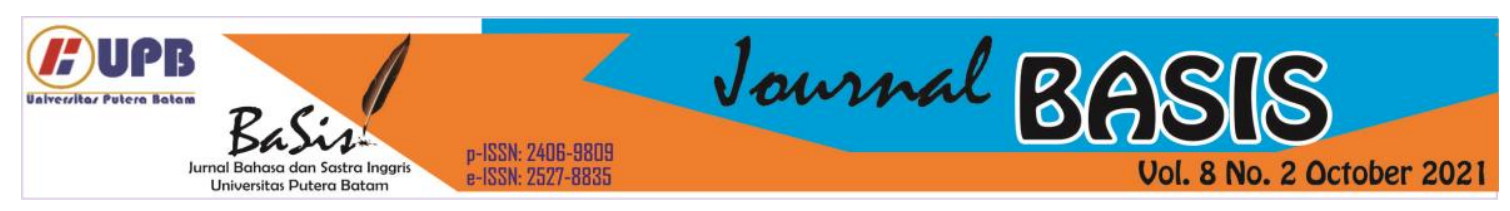

\title{
THE PORTRAYAL OF PANDEMIC IN AMERICAN MOVIES
}

\author{
Rudy ${ }^{1}$ \\ Universitas Prima Indonesia, Medan, Indonesia \\ rudyl@unprimdn.ac.id \\ Firman Arofati Zalukhu ${ }^{2}$ \\ Universitas Prima Indonesia, Medan, Indonesia \\ firmanzal810@gmail.com \\ Kevin Susanto Manurung ${ }^{3}$ \\ Universitas Prima Indonesia, Medan, Indonesia \\ kevinmanurung756@gmail.com
}

\begin{abstract}
With the purpose of understanding the pandemic issue that is currently experienced by almost all countries, this library research examines American films with a pandemic theme to find out the reason for using this theme in films and to identify the symbol of pandemic shown in the films. By observing the dialogs and scenes in Outbreak (1995), I am Legend (2007), Carriers (2009), Contagion (2011), and The World War Z (2013), this textual analysis study utilizes the theory of representation to interpret the pandemic in the films. The results showed that the pandemic issue can be considered a promising theme because the concept of the theme includes interesting scenes such as the emergence of infectious disease, rapid virus transmission, high mortality rates, and challenges in overcoming pandemic. These scenes form a pattern - confusion, panic, emergency, survival, and treatment that can be the hallmark of a pandemic-themed film. In addition, the results of the study also suggested that films about pandemics can symbolize the reality of human's life which is reflected through the portraits of greed, heroism, and hope.
\end{abstract}

Keywords: pandemic, American films, the concept of pandemic, the symbol of pandemic

\section{INTRODUCTION}

The word "pandemic" has terrorized everyone in the world. Millions of people have been suffered from the deadly illness known as Corona Virus Disease (Covid)-19. It spread very fast to almost all countries in the world. Almost all countries have been trying to do whatever they can to save more lives. In the era of globalization, pandemic is not something new (Antràs et al., 2020, p. 1 ). the year 2020 became a tough year for all the people in the world due to the highly contagious virus which caused a serious impact to almost every aspect of

human's life, not only physically but also mentally.

Due to the spread of this deadly virus, there is a serious impact that people can see in social life including economic sector, education, psychology, etc (Joint Advisor, 2020, p. 11). This means, pandemic must be handled carefully and professionally so that it will end. However, to stop the spread of infectious disease, every country has face many problems. Due to the policies set by many countries, the year 2020 was a hard time every country. Many cities were locked 
down. Stores, restaurants, malls and schools were closed. Many countries forbid public gatherings and events. These all have caused a serious problem in the world's economy (Abidah et al., 2020 , p. 38). Its impact has been surprisingly serious to the world and thus, it is regarded as a world-wide catastrophe (Cheval et al., 2020, p. 1).

Since the issues centered on pandemic Covid-19 have become one of the main topics in all countries, people have huge interest in knowing more about it. The spread of infectious diseases can attract a lot of people to learn and understand better (Adalja et al., 2018, p. 8), this can be considered as a phenomenal topic to discuss. For this reason, the idea of selecting this topic is influenced by the circumstances faced by everyone during the pandemic. This makes the pandemic issue an object that needs to be studied, especially if it is related to the image shown by the films.

Films play an important role in society as a part entertainment media. In addition, it is also important to know that films can display symbols which can show certain images, especially those related to human's life because films function as media to express what people feel and think (Watson, 2003, p. 9 ). Therefore, movies can also enrich people's knowledge (Adi, 2011, p. 71). From the ideas above, it is clear that the issue or objects depicted in films can convey certain meanings that people need to understand. American movie producers, for example, want to portray certain phenomenal issues in society because those depictions are experienced by people.

There have been many movies with pandemic themes. However, as the world has been battling a pandemic, the talk of pandemic seems to be something important important. At the same time, this study can be more interesting because it discusses the pandemic issue represented in American films. Therefore, this study explores the pandemic issues represented in American films. Regarding the points explained above, this study has two intentions as followings: (a) to understand the reasons pandemic is used as a theme in American films and (b) to identify how pandemic is portrayed in American films as an illustration to understand the current condition of pandemic faced by the world.

This study focuses on discussing the concept of pandemic used in American films. American movies on pandemic have been widely watched by many people, particularly those which use popular actors as the main characters. There are five American movies used in this study - Outbreak (1995), I am Legend (2007), Carriers (2009), Contagion (2011), and The World War Z (2013). These films depict about pandemic experienced by human beings. Even though there are still many more movies portraying pandemic, the five films above are selected to be analyzed because these American films have been shown widely in many countries, especially in Indonesia. Theoretically, it aims at contributing to the development of theories in humanities especially in media studies, film studies, cultural studies as well as literary studies. Practically, it is for improving people's understanding about the significant values and knowledge behind the pandemic depicted in American films which can be useful for everyone to see and learn about the reflection of social and cultural issues in society. By this way, people can be aware of the need to obtain values of life from entertainment media such as films. 


\section{LITERATURE REVIEW}

The term "pandemic" used in this study generally means the disease which can easily and quickly passed on to others. Oxford Advanced Learner's Dictionary defines pandemic as "a disease that spreads over a whole country or the whole world (Wehmeier, 2000, p. 915). World Health Organization (2014, p. xviii) explains pandemic as "An epidemic occurring worldwide or over a wide area, crossing boundaries of several countries, and usually affecting a large number of people". In other words, a disease is commonly known as a pandemic if it spreads from one region to many countries (Morens et al., 2009, p. 1019). Some infectious diseases such as bubonic plague, yellow fever, pox, etc. were once terrifying pandemics in history (Beach et al., 2020, p. 6). Thus, the concept of pandemic used in this study is the disease caused by virus or bacteria that is easily spread to other people in a short time.

Since this study discusses the issue of pandemic in American films, the term "film" needs to be clarified in order to form a clear concept of film used in this study. The word "film" can also mean movie. Oxford Advanced Learner's Dictionary defines films as "a series of moving picture recorded with sound that tells a story, shown on TV or at the cinema." (Wehmeier, 2000, p. 473). In films, characters play an important role because an idea is dramatized through them (Adi, 2011, p. 57). In this $21^{\text {st }}$ century, film has been widely used to reflect popular culture (Turner, 2003, p. 2). The term film used in this study refer to audio-visual entertainment media that presents stories in the form of scenes with characters played by actors and watched by people in cinemas.
There have been many articles or reports discussing about pandemic in human's life, especially in health and medical sciences. For instance, Morens, Folkers, and Fauci (2009); Yamamoto (2013); Van, Jamison, and Summers (2018); Singer, Thompson, and Bonsall (2020); and Balkhair (2020) focused on the impact of pandemic in medical sciences and human's health. Their researches are mostly viewed from health science perspectives. However, this study discusses pandemic represented in entertainment media such as film, especially American movies which are usually well-known. This study can be more interesting and different from the other studies by interpreting the pandemic concept in American movies.

\section{RESEARCH METHOD}

This qualitative research intends to figure out as much information as possible from relevant data related to the issue discussed in the research (Hariwijaya \& Djaelani, 2004, p. 39; Creswell, 2010, p. 16). Therefore, the data collected for the research is in the form of statements not in the forms of numbers (Hasan, 2002, p. 83). Social and cultural phenomena, issues, portrayals, dialogs, etc. commonly used in social studies because it can help researchers get data sufficiently and efficiently (Glaser \& Strauss, 1967, p. 18). The movies selected as primary data are those shown in many countries because there were famous actors playing main characters in them such as Outbreak (1995), I am Legend (2007), Carriers (2009), Contagion (2011), and The World War Z (2013). This textual analysis study applied for analyzing the data is semiotic approach to interpret the symbols which form people's perception (Berger, 2010, p. 25). Dialogs or scenes obtained from the 
films are considered as symbols which can be interpreted to represent a meaning as shown in the following scheme:

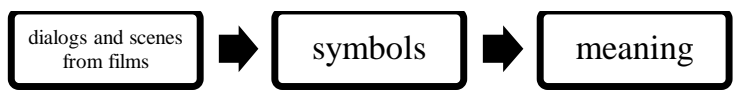

The meaning those symbols represent can be related to culture (Hall, 1997, p. 15). The pandemic issue portrayed in films can symbolize certain meanings which can be connected to human's life, culture, society and so on.

\section{RESULT AND DISCUSSION}

The result of analysis showed that pandemics could become a promising theme in American films and the pandemic theme in American films is generally depicted with the same formula. Further, the research result also revealed that pandemic issues in American films can show several significant portraits related to the reality of human life.

\subsection{Pandemic as a Theme in American Films}

Pandemic issue is a common theme in films, especially American films. This theme has increasingly discussed lately because since 2020, the world has been hit by the Covid-19 pandemic which has resulted in many losses, including death to many countries. Among the films with a pandemic theme, some of the famous ones are Outbreak (1995), I Am Legend (2007), Carriers (2009), Contagion (2011), and The World War Z (2013) which were analyzed in this study. These five films tell the story of the pandemic experienced by mankind and the various kinds of conflicts related to it.

As what has been experienced by most people in the world since 2020 , the emergence of a disease caused by an outbreak of virus is usually sudden and fast (Morens et al., 2009, p. 1018). This has also been explained by WHO that a pandemic is often associated with the fast spread and the infection from a new type of virus is likely to continue in human's life (WHO Guidelines, 2014, p. 7). The medical world argues that the virus ranks first as the cause of the most dangerous pandemic such as the flutype virus (Adalja et al., 2018, pp. 1415). This condition is portrayed in films with pandemic themes. The films discussed in this study show the spreading pandemics come from a new type of virus. This condition is similar to the concept expressed by experts from the medical field regarding the characteristics of infectious disease caused by virus.

Although the definition of a pandemic has not been fully defined by medical experts because the concept can change from time to time (Qiu et al., 2016, p. 9), the term "pandemic" will still emerge as something new and frightening. This fact provides a picture of the emergence of new type of virus that infects humans with rapid spread and results in death will make people afraid and anxious. This is related to the idea that the pandemic issue can be perceived as something close to society. Therefore, this theme can be seen as a theme to be reckoned with in the world of film and may be considered as a genre. According to Adi, in popular fiction, genre may also be interpreted as a type that can be classified with certain characteristics and it can be created to attract audience's interest (2011, p. 82). For that reason, the genre of film can describe the fulfillment of hopes and pleasure (Buckland, 2003, p. 104). Thus it is essential to know the things that make such films become interesting. The concept of pandemic theme in films frequently show plots which include "a new disease", "fast transmission", 
"increasing rate of mortality" and "Challenge to cure" A pandemic caused by a deadly virus can generally be described as a new disease; transmission that occurs rapidly and extends to various regions and can even reach the entire world; circumstances that cause the mortality rate to increase; and challenges to overcome and cure the disease.

The anxiety and fear of a pandemic which could cause devastation for every country seemed to be felt by people who enjoy this kind of genre. This is also an advantage that can be considered as the attraction of films about pandemic. Film as a product of popular culture must be able to provide entertainment for the audience and that is its characteristic (Sklar, 1975, p. 5). Therefore, filmmakers aim to draw the audience's attention and satisfy them. So, filmmakers may use the four elements involved in the conceptualizing the term "pandemic" as an attracting force in pandemic-themed films. Pandemic issue is used as a theme in films because there is a sense of shock and a tense sensation when seeing a new kind of virus causing a new disease that spread rapidly. A type of film that gives viewers a sense of tension can relate to a person's mental and emotion state (Morgan, 2002, p. 91) which is certainly the right means to entertain the audience. Even though its purpose is as a means of entertainment, films about a deadly pandemic can somehow arouse the audience's emotion, for instance, the emergence of fear in audience.

Pandemic-themed films show a fatal virus infecting humans and panic sweeps across cities, countries, and even the world. This may lead to fear because viruses are real in human life and are capable of causing deadly diseases to humans. The virus that spreads and results in death for mankind is a threat to humans, so, fear will inevitably arise. This is because fear is a natural and fundamental feeling that everyone has for responding to threats (Gürson, 2011, p. 208; Prohászková, 2012, p. 132). Viruses that cause deadly disease; fast transmission; the increasing number of victims who die from the disease; and the absence of medication to cure the disease are the points which can arouse fear in audiences who watch pandemic-themed movies. This fear can be used by filmmakers in entertainment to create plots and scenes that may cause fear to viewers.

The thoughts above may form a kind of pattern that can be seen as a hallmark of films on pandemic. The pattern can be understood as a formula that makes the characteristic of something and that may appear different from others. Formula generally refers to elements that are found in popular fiction, for instance, a film (Adi, 2011, p. 208). The formula that can be observed from a film with a pandemic theme is: confusion because of the unknown disease; panic caused by the rapid outbreak; emergency state for the increasing death rate; surviving in hard times under the uncontrollable situations; and treatment which shows determination to fight the pandemic. The pattern that appears in films about pandemic is, first, the emergence of a deadly disease from an unknown virus or parasite. This causes confusion and curiosity to humans. The below dialog may serve as an example that the presence of an unknown virus is seen as a pattern in films about pandemics:

Casey : Jesus Christ, five hours? It infects the cell, replicates and kills this fast? These numbers can't be right. Ebola takes days to do this damage.

Outbreak (1995) - 00:25:29 
Woman : So it's an epidemic now. An epidemic of what?

Dr. Mears : In 72 hours, we'll

know what is, If we're lucky

Contagion (2011) - 19:00:00

Karin : What is that, Gerry? What is

that?

Gerry : I don't know!

The World War Z (2013) 00:94:46

Second, the deadly virus infects humans in a short time and transmits from one individual to another. It spreads to various regions and even to many countries. The rapid outbreak can surely cause panic to people as they worry and fear that they may be infected. As an example, this can be seen from the dialogs shown in the films:

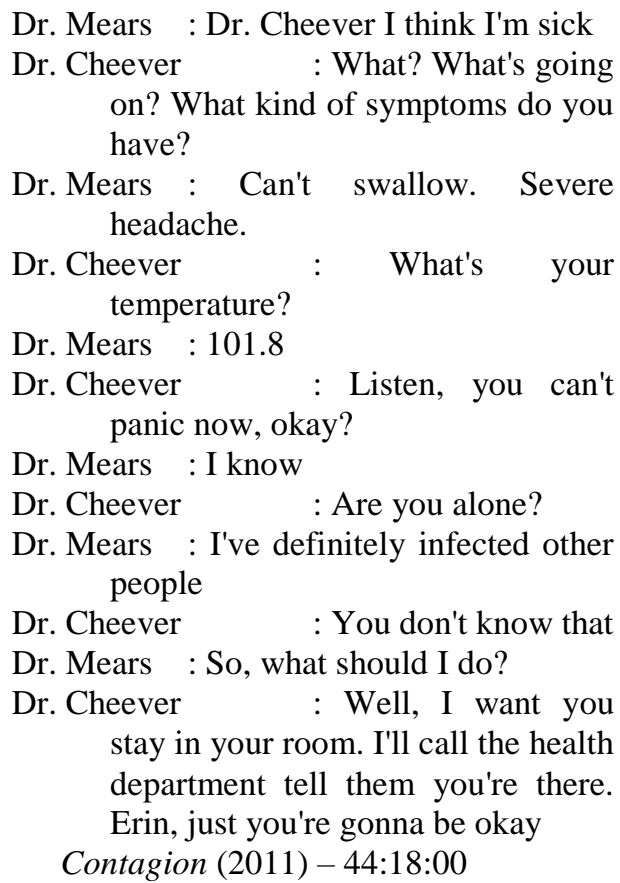

Third, because the death rate is rapidly increasing, there is emergency. People take precautions such as keep their distance from others, staying at home, wearing masks, washing their hands with soap, using antiseptic solutions, and so. This element is also a characteristic of the pandemic-themed film patter which can be seen from the following examples:
Man: A military curfew is now in effect. Return to your homes immediately. Anyone found on the streets after 19:00 hours, or 7:00 PM, will be arrested and confined. Return to your homes. You will be safe there. Return to your homes immediately.

Outbreak (1995) - 01:00:35

Man 1 : Unless you have clearance. You cannot pass the check point. Please return to your homes.

Man 2 : You're clear. Move ahead. Military quarantine is about to begin.

I Am Legend (2007) - 00:40:55

Brian: Avoid the invefted at all costs, their breath is higly contagious. Disinfect anything they have touched in the last 24 hours. The sick are already dead. They cannot be saved. You break the

them you live. rules you Die. You follow

Carriers (2009) - 00:04:45

Dr. Cheever : Well Dr. Grupta there continue to be evaluations of several drugs. Ribavirin is among them. But right now, our the best defense has been social distancing. No handshacking, staying home when ou're sick, washing your hands frequently. Contagion (2011) - 54:43: 00

Forth, the situations that are out of control trigger everyone to survive in fear and anxiety. This can be seen in scenes where people struggling in a state of fear of losing their lives. Many who could not survive would have to end their lives.

Dr. Mears : You gotta send somebody else

Dr. Cheever : Yes, but you don't worry about that right now, okay? You take care of yourself

Dr. Mears : I'm sorry I couldn't finish

Dr. Cheever : That's Never mind. Let me see what I can do about getting you back here. I'm 
gonna get you home if I can, healthy... Now, you hang in there Contagion (2011) - 44:18:00

Brian : Shoot me or take me with you. Danny : Brian, don't do it

Brian : I'm not gonnaeand up like them, Danny. Rotting alive, alone. You can't tell whether they're

alive or dead. It's what we decided, I'm dying Danny.

Carriers (2009) - 01:13:28

Fifth, the determination and persistence of humans to fight the pandemic and survive survive will lead them to think of ways to treat and overcome the spread of the virus, for example, by creating a vaccine.

Casey: I hate this bug.

Sam: Come on, Casey. You have to love its simplicity. It's one billionth our size and it's beating us.

Casey: What then?

Sam: Kill it.

Outbreak (1995) - 00:25:29

For that reason, the pattern of films on pandemic will feature thrilling plots and adrenaline-inducing scenes that are favored by film viewers in general. US film producers view the pandemic issue as a popular theme in society because disease outbreaks, are basically part of human life, especially during the Covid19 pandemic as it is being experienced by all countries in the world. The concept of pandemic used as a theme in the film can show a certain pattern that will be a characteristic of the film. This pattern can be considered as a film genre that is able to raise people's interest to watch.

\subsection{Symbols behind the Pandemic Theme in American Films}

The pandemic issue which is used as the theme contains symbols that are significant to be understood. The result of analysis suggest that a pandemic theme in films can indicate several elements that can describe human life - the portraits of greed, heroism and hope.

\subsubsection{The Portrait of Greed}

Behind the ferocity of the pandemic that can cause the number of victims to die in a short time, there is a picture of the greed that exists in humans. The five films about pandemic discussed in this study can reflect a portrait of people's greed for certain intentions which can often cause environmental damage that triggers problems. Greed portrayed in Outbreak (1995) showed a group of irresponsible people who gain profits by smuggling wild animals from the jungle via ships as shown in the following dialog:

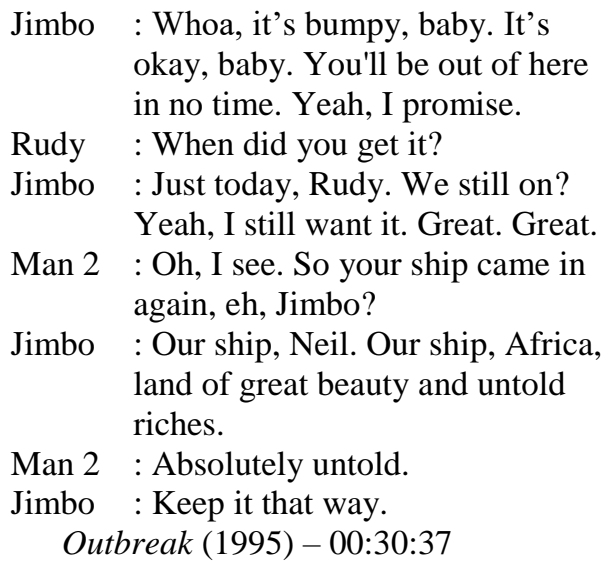

They do not realize that the wild monkey from the forest they smuggle in carries a dangerous virus that can infect humans in a short time. In I Am Legend (2007), for example, the chaos and destruction arise because people infected with viruses become wild and attack humans and turn them into their species. The greed of scientists who engineered a virus for a medical treatment led to catastrophe that caused the virus to turn humans into another kind of vampire-humans, for instance: 
Dr. krippin : Well, the premise is quite simple. Take something designed by nature and

reprogram it...to make it work for the body rather than against it. News Woman : We're talking about a virus?

Dr. krippin : Yes. In this case, the measles virus.......which has been engineered at a genetic level to be helpful rather than harmful .Um, I'm not... I find the best way to describe it is......if you can imagine your body as a highway.......and you picture the virus as a vvery fast car being driven by a very bad man......imagine the damage that that car could cause. But then if you replace that man with a cop....the picture changes. And that' essentially what we've done.

News Woman : Now, how many people have you treated so far?

Dr. krippin : Well, we've had 10,009 clinical trials in humans so far. I Am Legend (2007) - 00:00:56

In Contagion (2011) for instance, there is a scene showing that there are people who take advantage of the pandemic situation to gain advantage by spreading the word about conspiracy theories:

: That's right. They trust me, all
12 million unique visitors. I'm a
trusted man stepping up to a
microphone in front of a very
large crowd. That's who I am.
That's the brand. I say the right
thing, nobody shows up for their shot.
Maybe they'd rather roll the dice
with forsythia. I can make that
happen. I just wanna know I'm in
the best position possible
Contagion (2011) - 01:20:07

The last part of Contagion showed that there was a company clearing a forest land for businesses which in turn caused the habitat of bats to be disturbed and a bat infected a pig. The pig then infected the people who buy it. That is the process of infection and it continues to reach a lot of people in an area and will spread to other areas even to the whole world.

Many people think that greed has caused a lot of suffering in human life (D'Souza, 2015, p. 1). Perhaps in general, people think that greed is a natural human trait. However, this has not been completely proven. There is a perception that greedy people are those who take advantage from others and sacrifice others (Cardella et al., 2019, p. 594). While others may define greed as actions that are considered excessive by giving burdens and taking away the welfare of others (Wang et al., 2012, p. 7). Greed can be interpreted as a characteristic of someone who wants something excessively without caring for the needs of others and tends to be detrimental to others.

The picture of human greet that causes the spread of deadly viruses is reflected in the films. The Motaba Virus is due to the smuggling of monkey is shown in Outbreak (1995); I Am Legend (2007) portrays a modified Krippin Virus used for medical purposes; and MEV-1 in Contagion (2011) from disturbing habitat of bats due to land clearing in the rain forest by a company. The portrait of human greed shown in the film results in great losses to mankind in the form of death, chaos, fear, trauma, bankruptcy, and so on. Many people are greedy when it comes to making profits for themselves. Greed can also make people do things that violate the law and are not ethical only for their sake. Greedy people do not care about the consequences of their greed on others. Therefore, it will bring disaster to others. Whatever form of greed, will have a negative impact on human life (Vries, 2016, p. 7). All forms of greed will bring suffering to oneself and others. People will stop being greedy as soon as disaster strikes. However, after everything turns to 
normal, people begin to show their greediness by exploiting the natural resources which can lead to forest destruction and disturbance of animal habitats in it. Thus, the explanations above can be interpreted that problems happen in society, including the outbreak of infectious disease from viruses, can be related to the instability occurs in the environment. The pandemic is indirectly caused by the humans who intend to gain as many profits as possible without thinking about the harmful effects that might occur.

\subsubsection{The Portrait of Heroism}

Another portrait that the pandemic films showed was heroism. The spirit of heroism appears in a pandemic-themed film because basically a film that tells about a disaster shows people who try to put all his efforts to help overcome the disaster. These people are usually the main characters who are trusted to solve the problems shown in the film. The following dialogs portray heroism:

Dr. Ally: Do you remember Dr. Barry Marshall? Thought that bacteria causes ulclears, not stress.

Gave himself the bug and then cured himself. You taugh me about him. I'm testing my

vaccine.

Dad : No, this is diffrent. I don't want to get you sick. Ally, you can't take that chance.

Dr. Ally: Oh, Dad you're here because you stayed in your practice treating sick people after everyone else went home. You took that chance. You took that chance everyday.

Contagion (2011) - 01:16:05

Man 1 : What happened to Gerry? Not that one. Not that one.

Brit : Jesus. He's going to inject himself. We have no idea which one's going to work. We don't know if any of them will work.

Woman 1: How long does he have to wait?

Man 1 : Before he's infected? Not long, but, that's not the question we're really asking, is it?

Look at them.

Man 2 : He just walked right past him! He walked right past him!

The World War Z (2013) - 01:4: 09

The character Sam in Outbreak (1995) is not afraid to be arrested as long as people can stay at home to prevent the transmission of the virus. It can be seen from the above dialog that there is an attitude of self-sacrifice for people which is significant to describe the spirit of heroism:

Sam : You got 19 dead, you got hundreds more. infected and it's spreading like a brushfire. You gotta isolate the sick, and I mean really isolate them. We gotta get everybody else back into their houses.

Billy : We're doing that!

Sam : No, we're not doing it! Because I just drove through 100 people! If one of them has got it, then 10 of them have it. If one gets out of Cedar Creek, Billy, then we're in deep f**ing s*it! And we're already in deep $\mathrm{f}^{* * * i n g} \mathrm{~s} * * \mathrm{t}$ ! If you're gonna arrest me, arrest me now!

Outbreak (1995) - 00:55:21

"Heroism" may be interpreted from various points of view and depends on the person who defines it. According to Franco et al. (2016, p. 11), Although heroism today can be interpreted widely by everyone, the deeper meaning of the term is still something that is rarely expressed. The heroes frequently shown in films about pandemics are those with important professions who play an essential role in emergency situations. These people are called everyday heroes such as medical personnel, fire teams, educators, etc. 
(Keczer et al., 2016, p. 7). The heroic spirit in these films is portrayed through the presence of doctors, virologists, police, and agents of United Nations who are trying with all their strength to help people affected by the virus. The film I Am Legend (2009) for example, portrays a virologist who put all his strength to help other survivors:

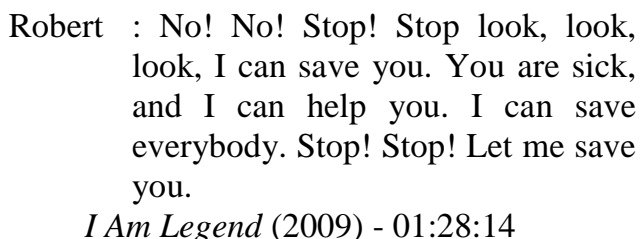

Heroism is often perceived as the highest point of human behavior and people have a desire to reach the status of heroism in their lives (Franco et al., 2011, p. 99). In addition, the spirit of heroism is created in oneself and heroism must revealed at essential and urgent times. (Štaud \& Oborny், 2015, p. 328). The heroic characteristic is praised by people and a figure with this kind of characteristic is indispensable in society, especially in a disaster situation. In a critical pandemic situation due to the fear and anxiety that people experience, a heroic figure is necessarily needed for stability.

\subsubsection{The Portrait of Hope}

Pandemic issue in the films can also be interpreted from the emergence of a portrait of hope. The hope portrayed in the films was a chance to survive through scary times of emergency. There were people who could eventually survive the pandemic that had cause a very high death rate. Hope becomes a portrait that is often found in pandemic-themed films, for instance:

Sam : Make more, we got a town waiting. It's gonna work, sir. Go, go. Come on. The time's now. We have an antiserum. As we speak, it's being administered. Every infected person within a matter of hours will have their dosage...

Outbreak (1995) - 01:49:02

The hope shown in Outbreak (1995) is the discovery of a serum that can provide benefits to the immune system against viruses. The discovery of antiserum can symbolize the hope to survive even though the pandemic is not over yet. Other films about pandemics also portray hope for survival, as shown in the following examples:

Anna: My name is Anna Montez. There are other survivors I'm travelling with dr. Robert Neville and a boy name Ethan. We're heading north on route 17 to bethel, Vermont. Keep your radio on, listen for our broadcasts. You are not alone. There is hope, keep listening, you're not alone.

I Am Legend (2007) - 01:34:41

Danny :... I wait, but nothing happens to me, and for the first time, I feel like I am alone in the world. We made it. Two strangers with nothing left to say. Brian and I used to love this place, the hotel, the beach. They still look exactly the same, but they're just places now.

Carriers (2009) - 01:15:08

Newsman 3: The World Health Organization has created a vaccine that works as a kind of camouflage making people who receive it invisible to the infected.

Newswoman : Volunteer forces are delivering the vaccine to areas that have been cordoned off

Man : Distribution efforts began in earnest on April 10th

Newswoman : The importance of getting the information out to those still alive within the quarantine.

Gerry : But it's given us a chance. 
Military official : If you can get to a
colder area to higher ground, they
move slower on the ground.
French newsman : Initial tests on the so-called camouflage have been largely successful.

The World War Z (2011) - 01:53:28

Hope has a positive meaning. If there is a hope depicted in something (including films), there will be a good thing happens. This is also mentioned by Hassan et al. (2018, p. 1452) that hope is related to optimism which can be perceived as a positive reaction and will form a good chance in the future. It can signify good things that will occur in the future. The portrait of hope is obviously depicted through finding a way to stop the spread of the virus such as creating vaccines, migrating to a safer area, etc. According to Snyder (2002, p. 268) hope plays an essential role in improving someone's life quality. This can be interpreted that having hope can encourage people to appreciate their lives more. A person who has the principle that his or her life is valuable, will develop a more selfaware attitude and will avoid things that can harm his or her life. Therefore, hope can help decrease the bad effects of despair because it gives people strength (Huen et al., 2015, p. 14). The picture of hope shown in the films can be perceived as a significant symbol in pandemic-themed films. Besides fulfilling the expectations of film audiences as popular culture products, this may also reflect that the human's strength to survive may create a hope. In addition, hope in reality can show a way out to overcome a problem and to achieve a better condition.

So, the issue of pandemic in American films is symbolized as a greed, heroism and hope in human's life. In other words, behind the pandemic disaster, there is a picture of human's greed that destroys nature and its surroundings for their own benefits and causes destruction; a picture of a heroic soul found in people who struggle to help the sick and restore the stability in society; and a picture of hope which refers to the sense of optimism about good things that will happen in the future. The three portraits can reflect that humans in reality will face these three conditions. Therefore, apart from being a means of entertainment, films about pandemics can also be useful to increase knowledge about the pandemic, particularly during the Covid-19 pandemic that is currently engulfing the world.

\section{CONCLUSION}

There are several three essential points that can be concluded in this study. Firstly, the issue of pandemic has become an interesting theme in American films. Several popular American films with pandemic themes such as Outbreak (1995), I Am Legend (2007), Carriers (2009), Contagion (2011), and The World War Z (2013) could attract audiences. This is because the concept of the theme - the emergence of new infectious disease, fast transmission, high death rate and the challenges of overcoming the pandemic seem to be able to attract audiences. The pandemic concept shown in the films created a pattern confusion, panic, emergency, surviving, and treating which is commonly found in films about pandemics. This pattern can be considered as a promising genre in film because it can attract people to watch.

Secondly, the pandemic in the American movies discusses in this study can symbolize the conditions that humans experience in the reality. This can be seen through: 
(a) the portrait of greed which shows that the pandemic disaster is related to the greedy characteristic of humans who want to gain more profits without caring about other people, environment, and the nature.

(b) the portrait of heroism which reflects the existence of brave figure who struggle to save people who are suffering.

(c) the portrait of hope which shows that hope can increase optimism and indicates positive things in the future.

Finally, This study also suggests that pandemic-themed films are perceived as entertainment media that contain educational values, especially in developing good characteristics during the pandemic time as the world is currently facing.

\section{REFERENCES}

Abidah, A., Hidaayatullaah, H. N., Simamora, R. M., Fehabutar, D., \& Mutakinati, L. (2020). "The Impact of Covid-19 to Indonesian Education and Its Relation to the Philosophy of "Merdeka Belajar."' Studies in Philosophy of Science and Education, 1(1), 38-49. https://doi.org/10.46627/sipose.v1i 1.9

Adalja, A., Watson, M., Toner, E., Cicero, A., \& Inglesby, T. (2018). The Characteristics of

Pandemic Pathogens. Maryland:

Johns Hopkins Bloomberg School of Public Health, Center for Health Security.

Adi, I. R. (2011). Fiksi populer: Teori \& metode kajian. Yogyakarta: Penerbit Pustaka Pelajar.

Antràs, P., Redding, S. J., \& RossiHansberg, E. (2020). Globalization and Pandemics. National Bureau of Economic Research Working Paper Series (No. 27840).

Beach, B., Clay, K., \& Saavedra, M. H.
(2020). The 1918 Influenza Pandemic and Its Lesson for Covid-19. National Bureau of Economic Research Working Paper Series (No. 27673). http://www.nber.org/papers/w2767 3

Berger, A. A. (2010). The Object of Affection: Semiotics and Consumer Culture. New York: Palgrave Macmillan.

Buckland, W. (2003). Teach Yourself FIlm Studies. Chicago: Contemporary Books.

Cardella, E., Kugler, T., Anderson, J., \& Connolly, T. (2019). "Is Greed Contagious? Four Experimental Studies." Journal of Behavioral Decision Making, 32(5), 579-598.

Cheval, S., Mihai Adamescu, C., Georgiadis, T., Herrnegger, M., Piticar, A., \& Legates, D. R. (2020). "Observed and Potential Impacts of the COVID-19 Pandemic on the Environment." International Journal of Environmental Research and Public Health, 17(11:4140), 1-25. https://doi.org/10.3390/ijerph1711 4140

Creswell, J. W. (2010). Research Design Pendekatan Kualitatif, Kuantitatif, dan Mixed (3rd ed.). Yogyakarta: PT Pustaka Pelajar.

D’Souza, J. (2015). "Greed: Crises, Causes, and Solutions." International Journal of Humanities and Social Science, 5(7), 1-6.

Franco, Z. E., Allison, S. T., Kinsella, E. L., Kohen, A., \& Langdon, M. (2016). "Heroism Research: A Review of Theories, Methods, Challenges, and Trends." Faculty Publications: Political Science, 87, $1-15$.

Franco, Z. E., Blau, K., \& Zimbardo, P.

G. (2011). "Heroism: A 
Conceptual Analysis and Differentiation between Heroic Action and Altruism." Review of General Psychology, 15(2), 99113.

Glaser, B. G., \& Strauss, A. L. (1967). The Discovery of Grounded Theory: Strategies for

Qualitative Research. New York: Aldine de Gruyter.

Gürson, P. (2011). "Fear Culture." International Journal of Humanities and Social Science, 1(4), 208-213.

Hall, S. (1997). Representation: Cultural Representations and Signifying Practices. London: SAGE Productions.

Hariwijaya, M., \& Djaelani, B. M. (2004). Teknik Menulis Skripsi \& Thesis. Yogyakarta: Zenith publiser.

Hasan, M. I. (2002). Pokok-Pokok Materi Metode Penelitian dan Aplikasinya. Bogor: Ghalia Indonesia.

Hassan, K., Sadaf, S., Saeed, A., \& Idrees, A. (2018). "Relationship between Hope, Optimism and Life Statisfaction among Adolescents." International Journal of Scientific \& Engineering Research, 9(10), 1452-1457.

Huen, J. M. Y., Ip, B. Y. T., Ho, S. M. Y., \& Yip, P. S. F. (2015). "Hope and Hopelessness: The Role of Hope in Buffering the Impact of Hopelessness on Suicidal Ideation." PLoS ONE, 10(6), 1-14.

Joint Advisors. (2020). Improving Pandemic Preparedness and Management. Brussel: The

European Commission by the Group of Chief Scientific Advisors (GCSA), the
European Group on Ethics in Science and New Technologies (EGE), and Peter Piot as

special advisor to European Commission President Ursula von der Leyen on the response to the coronavirus and COVID-19.

Keczer, Z., File, B., Orosz, G., \& Zimbardo, P. G. (2016). "Social Representations of Hero and Everyday Hero: A Network Study from Representative Samples." PLoS ONE, 11(8), 1-17.

Morens, D. M., Folkers, G. K., \& Fauci, A. S. (2009). "What Is a Pandemic?" The Journal of Infectious Diseases, 200(7), 10181021.

https://doi.org/10.1086/644537

Morgan, J. (2002). Biology of Horror: Gothic Literature and Film. Illinois: Southern Illinois University Press.

Prohászková, M. V. (2012). “The Genre of Horror." American International Journal of Contemporary Research, 2(4), 132-142.

Qiu, W., Rutherford, S., Mao, A., \& Chu, C. (2016). "The Pandemic and Its Impact." Health, Culture and Society, 9(10), 2-11.

Sklar, R. (1975). Movie-Made America: A Cultural History of American Movies. New York: Random House, Inc.

Snyder, C. R. (2002). "Hope Theory: Rainbows in the Mind." Psychological Inquiry, 13(4), 249275.

Štaud, O., \& Oborny், J. (2015). "Hermeneutics of (Sport) Heroism." Journal of Human Sport \& Exercise, 10(1), 320-329.

Turner, G. (2003). Film as Social Practice. New York: Routledge.

Vries, M. F. R. K. de. (2016). "The Greed Syndrome”. INSEAD 
Working Paper (2016/26/EFE).

Wang, L., Malhotra, D., \& Murnighan, J. K. (2012). "Economics, Education, and Greed." Academy Management Learning \& Education, 10(4).

Watson, R. (2003). Film and Television in Education: An Aesthetic Approach to the Moving Image. London: The Falmer Press.
Wehmeier, S. (2000). Oxford Advanced Learner's Dictionary (6th ed.). Oxford: Oxford University Press.

World Health Organization. (2014). Infection Prevention and Control of Epidemic-and

$$
\text { Pandemic-Prone Acute }
$$

Respiratory Infections in Health Care. Geneva:

Author. 